Federal Reserve Bank of Minneapolis

Research Department Staff Report 210

April 1996

\title{
A Self-Fulfilling Model of Mexico's 1994-95 Debt Crisis
}

\author{
Harold L. Cole*
}

Federal Reserve Bank of Minneapolis

Timothy J. Kehoe*

University of Minnesota

and Federal Reserve Bank of Minneapolis

\begin{abstract}
This paper explores the extent to which the Mexican government's inability to roll over its debt during December 1994 and January 1995 can be modeled as a self-fulfilling debt crisis. In the model there is a crucial interval of debt for which the government, although it finds it optimal to repay old debt if it can sell new debt, finds it optimal to default if it cannot sell new debt. If government debt is in this interval, which we call the crisis zone, then we can construct equilibria in which a crisis can occur stochastically, depending on the realization of a sunspot variable. The size of this zone depends on the average length of maturity of government debt. Our analysis suggests that for a country, like Mexico, with a very short maturity structure of debt, the crisis zone is large and includes levels of debt as low as that in Mexico before the crisis.
\end{abstract}

*We are grateful to seminar participants at several institutions, especially to Carlos Vegh and Edward Green and to two anonymous referees. The research of the second author has been supported by a grant from the Air Force Office of Scientific Research, Air Force Material Command, USAF, under grant number F4962094-1-0461. The U.S. government is authorized to reproduce and distribute reprints for government purposes not withstanding any copyright notation thereon. The views expressed herein are those of the authors and not necessarily of the Federal Reserve Bank of Minneapolis, the Federal Reserve System, the Air Force Office of Scientific Research, or the U.S. government. 


\section{Introduction}

In its weekly auctions of bonds during December 1994 and January 1995, the Banco de México found it difficult to roll over Mexico's government debt. This paper explores the extent to which this phenomenon can be explained using the model of self-fulfilling debt crises developed by Cole and Kehoe (1996a): Investors feared that Mexico would be unable to honor its commitments on bonds coming due. This made investors unwilling to purchase new bonds. Unable to sell new bonds, Mexico was forced into a position where default seemed inevitable, and the expectations of investors that Mexico would be unable to honor its commitments were justified.

One of the surprising aspects of the Mexican debt crisis is that it occurred despite the fact that the Mexican government's fiscal behavior before the crisis appeared to be, on the whole, responsible, both with respect to its own past behavior and with respect to the behavior of many other countries that, at least as yet, have not experienced similar crises. This observation suggests that a crisis of this type may be somewhat arbitrary. Such an arbitrary aspect could arise if debt crises were self-fulfilling, in that a belief that the government would not be able to roll over its debt would make it optimal for the government to default, and hence no lender would be willing to lend to the government.

A number of papers have theoretically analyzed the possibility of such a self-fulfilling debt crisis; see for example, Calvo (1988); Alesina, Prati, and Tabellini (1990); and Giavazzi and Pagano (1990). Cole and Kehoe (1996a) develop a simple condition for the possibility of a crisis that depends on such fundamentals as the size of the government's debt, the maturity structure of the debt (in particular, the amount coming due), and the real cost associated with defaulting on the debt. They show that the probability of a crisis can be fairly arbitrary given that the conditions for a crisis are satisfied. This type of analytic analysis leaves open the question: Is a self-fulfilling debt crisis a plausible explanation of the Mexican debt crisis?

This paper presents a simple quantitative model in which we assess the ability of the Cole-Kehoe (1996a) model to explain the debt crisis in Mexico. We find that, for some initial values of government debt, this sort of self-fulfilling crisis can occur depending on the realization of a sunspot, a random variable not connected to the fundamentals of the model. If the initial level of government debt is in a crucial interval that we call the crisis zone, and 
if there is an unfavorable realization of the sunspot variable, there is a crisis. If there is a favorable realization of the sunspot variable, however, there is no crisis. When we calibrate our model to match Mexican data, we find that a crisis can occur for any value of the debt above 10 percent of GDP. The possibility of a crisis with such a low level of debt relative to GDP arises because of the extremely short average maturity of Mexico's domestic debtbarely more than 200 days in December 1994. Our model suggests that, if the debt maturity had been roughly twice as long, then a crisis would not have been possible.

\section{The Model}

The model follows closely that of Cole and Kehoe (1996a). There is a single good in each period, $t=0,1, \ldots$. This good can either be consumed or be saved as capital. Production utilizes capital and, implicitly, inelastically supplied labor. There are three types of people in the model: consumers, international bankers, and the government. We describe each in turn.

There is a continuum with measure one of identical, infinitely lived consumers. The consumers' utility function is

$$
E \sum_{t=0}^{\infty} \beta^{t}\left(c_{t}+v\left(g_{t}\right)\right)
$$

where $c_{t}$ is private consumption and $g_{t}$ is government consumption. We assume that $0<\beta<1$ and that $v$ is continuously differentiable, concave, and monotonically increasing. We also assume that $v(0)=-\infty$. The consumer's budget constraint is

$$
c_{t}+k_{t+1}-k_{t} \leq(1-\theta)\left(a_{t} f\left(k_{t}\right)-\delta k_{t}\right) .
$$

Here $a_{t}$ is a productivity factor that depends on whether or not the government has ever defaulted; $\delta, 0 \leq \delta \leq 1$, is the depreciation factor; $\theta, 0<\theta<1$, is the constant proportional tax on domestic income; and $f$ is a continuously differentiable, concave, and monotonically increasing production function that satisfies $f(0)=0, f^{\prime}(0)=\infty$, and $f^{\prime}(\infty)=0$. Each consumer is endowed with $k_{0}$ units of capital in period 0 .

Cole and Kehoe (1996b) explore a model in which consumers have a more general, concave utility of consumption and in which consumers can borrow from, and lend to, bankers. The assumption of risk neutrality of consumers greatly simplifies the modeling of consumer 
behavior. For example, it allows us to neglect the possibility of borrowing and lending without loss of generality.

There is also a continuum with measure one of identical, infinitely lived bankers. These bankers are risk neutral and have the utility function

$$
E \sum_{t=0}^{\infty} \beta^{t} x_{t}
$$

The assumption of risk neutrality of bankers captures the idea that the domestic economy is small compared to world financial markets. Each banker is endowed with $\bar{x}$ units of the consumption good in each period and faces the budget constraint

$$
x_{t}+q_{t} b_{t+1} \leq \bar{x}+z_{t} b_{t} .
$$

Here $q_{t}$ is the price paid for one-period government bonds that pay $b_{t+1}$ in period $t+1$ if $z_{t+1}=1$, but pay 0 if $z_{t+1}=0 ; z_{t} \in\{0,1\}$ is the government's default decision. We can choose the endowment $\bar{x}$ to be large enough that we can ignore corner solutions to the banker's utility maximization problem. Initially, each banker holds $b_{0}$ units of government debt. There is a constraint $b_{t+1} \geq-A$, where $A$ can be chosen large enough so that it rules out Ponzi schemes but does not otherwise bind in equilibrium.

There is a single government. In every period it chooses its new borrowing level, $B_{t+1}$; whether or not to default on its old debt, $z_{t}$; and the level of government consumption, $g_{t}$. If the government defaults by setting $z_{t}=0$, then productivity drops from $a_{t}=1$ to $a_{t}=\alpha<1$ from period $t$ onward. In period 0 , the government debt is $B_{0}=b_{0}$.

The government is benevolent in that its objective is to maximize the welfare of consumers. Its budget constraint is

$$
g_{t}+z_{t} B_{t} \leq \theta\left(a_{t} f\left(k_{t}\right)-\delta k_{t}\right)+q_{t} B_{t+1}
$$

As we shall see, we do not need to impose a borrowing constraint on the government to rule out Ponzi schemes because, if the government tries to sell too much new debt $B_{t+1}$, its price $q_{t}$ falls to zero. That the tax rate is constant captures the idea that changes in tax policy 
occur much more slowly than do debt crises.

In each period there is an exogenous sunspot variable, $\zeta_{t}$, whose value is realized. This variable is independently and identically distributed on the interval $[0,1]$. We can construct equilibria where, if the level of government debt $B_{t}$ is above some crucial level and $\zeta_{t}$ is below another crucial level, then international bankers are not willing to buy new government debt and the price of this debt is $q_{t}=0$. This unwillingness to buy government debt creates a selffulfilling debt crisis in the sense that, since the government cannot sell new debt, it chooses to default. If $\zeta_{t}$ is above the crucial level, however, international bankers lend to the government and no default occurs. The possibility of a debt crisis depends on the level of government debt: if $B_{t}$ is below the crucial level, then bankers know that the government will not default, whether or not they buy the new debt; they therefore buy the new debt.

The timing of actions within each period is important to the presentation of the model:

- $\zeta_{t}$ is realized, and the aggregate state is $s_{t}=\left(B_{t}, K_{t}, a_{t-1}, \zeta_{t}\right)$.

- The government, taking the price schedule $q_{t}=q\left(s_{t}, B_{t+1}\right)$ as given, chooses $B_{t+1}$.

- The international bankers, taking $q_{t}$ as given, choose whether to purchase $B_{t+1}$.

- The government chooses whether or not to default, $z_{t}$, and how much to consume, $g_{t}$.

- The consumers, taking $a_{t}$ as given, choose $c_{t}$ and $k_{t+1}$; in equilibrium $k_{t+1}=K_{t+1}$.

The essential aspect of the timing is that it enables the government to issue new debt before retiring the old debt while having a maturity of one period on the debt. The need to roll over old debt into new is what drives the crucial results of the paper. We could also obtain this feature by having longer maturity debt that is only partially rolled over in any period and some stock of reserves with which the government pays old debt becoming due, but it would complicate the analysis. In the final section we discuss the role of maturity in our results. Variants of the model can be obtained by having consumers make their choices at different points within the period and by delaying the imposition of the default penalty. Although these alternative timing assumptions would change the quantitative results of the model, they would not change its qualitative features. 


\section{Equilibrium}

A crucial feature of the model presented in the previous section is that the government cannot commit itself either to honor its debt obligations or to follow a fixed borrowing and spending path. We now define an equilibrium where agents choose their actions sequentially.

In defining such a recursive equilibrium, we work backward given the timing of actions in each period. We start with consumers because they move last. When an individual consumer acts he knows the following: his individual capital holdings, $k$; the aggregate state, $s=\left(B, K, a_{-1}, \zeta\right)$; the government's offering of new debt, $B^{\prime}$; the price that bankers are willing to pay for this debt, $q$; and the government's spending and default decisions, $g$ and $z$. Since the consumer's choices only depend on the price $q$ through its effect on $g$ and $z$, we define the state of the individual consumer to be $\left(k, s, B^{\prime}, g, z\right)$. The representative consumer's value function is defined by the functional equation

$$
\begin{aligned}
V_{c}\left(k, s, B^{\prime}, g, z\right)= & \max _{c, k^{\prime}} c+v(g)+\beta E V_{c}\left(k^{\prime}, s^{\prime}, B^{\prime}\left(s^{\prime}\right), g^{\prime}, z^{\prime}\right) \\
& \text { subject to } \\
& c+k^{\prime}-k \leq(1-\theta)(a(s, z) f(k)-\delta k) \\
& c, k^{\prime} \geq 0 \\
& s^{\prime}=\left(B^{\prime}, K^{\prime}\left(s, B^{\prime}, g, z\right), a(s, z), \zeta^{\prime}\right) \\
& g^{\prime}=g\left(s^{\prime}, B^{\prime}\left(s^{\prime}\right), q\left(s, B^{\prime}\left(s^{\prime}\right)\right)\right. \\
& z^{\prime}=z\left(s^{\prime}, B^{\prime}\left(s^{\prime}\right), q\left(s, B^{\prime}\left(s^{\prime}\right)\right)\right) .
\end{aligned}
$$

Here $B^{\prime}(s), g\left(s, B^{\prime}, q\right)$, and $z\left(s, B^{\prime}, q\right)$ are the government's policy functions, $q\left(s, B^{\prime}\right)$ is the price function, and $K^{\prime}\left(s, B^{\prime}, g, z\right)$ is the function that describes the evolution of the aggregate capital stock, all yet to be defined. The consumers' policy functions are $c\left(k, s, B^{\prime}, g, z\right)$ and $k^{\prime}\left(k, s, B^{\prime}, g, z\right)$. Because consumers are competitive, we need to distinguish between the individual decision $k^{\prime}$ and the aggregate value $K^{\prime}$ that are included in the description of the next period's state: consumers should not think that their individual actions affect the aggregate state in the next period, $s^{\prime}$, thereby affecting prices or the actions of the government. In equilibrium, because all consumers are identical, $K^{\prime}=k^{\prime}$. As we have explained, the produc- 
tion parameter $a$ satisfies $a(s, z)=1$ if $a_{-1}=1$ and $z=1$, that is, if the government has not defaulted in the past and has not defaulted this period; otherwise, $a(s, z)=\alpha$.

When an individual banker acts he knows his individual holdings of government debt, $b$, the aggregate state, $s$, and the government's offering of new debt, $B^{\prime}$. We therefore define the state of an individual banker to be $\left(b, s, B^{\prime}\right)$. The representative banker's value function is defined by the functional equation

$$
\begin{aligned}
V_{b}\left(b, s, B^{\prime}\right)= & \max _{x, b^{\prime}} x+\beta E V_{b}\left(b^{\prime}, s^{\prime}, B^{\prime}\left(s^{\prime}\right)\right) \\
& \text { subject to } \\
& x+q\left(s, B^{\prime}\right) b^{\prime} \leq \bar{x}+z\left(s, B^{\prime}, q\left(s, B^{\prime}\right)\right) b \\
& x \geq 0, b^{\prime} \geq-A \\
& s^{\prime}=\left(B^{\prime}, K^{\prime}\left(s, B^{\prime}, g^{\prime}, z^{\prime}\right), a\left(s, z^{\prime}\right), \zeta^{\prime}\right) \\
& g^{\prime}=g\left(s, B^{\prime}, q\left(s, B^{\prime}\right)\right) \\
& z^{\prime}=z\left(s, B^{\prime}, q\left(s, B^{\prime}\right)\right) .
\end{aligned}
$$

Because bankers are risk neutral and competitive, they are relatively passive: if $\bar{x}$ is sufficiently large, they purchase the amount of bonds offered by the government as long as the price of these bonds satisfies $q\left(s, B^{\prime}\right)=\beta E z\left(s^{\prime}, B^{\prime}\left(s^{\prime}\right), q\left(s^{\prime}, B^{\prime}\left(s^{\prime}\right)\right)\right)$, in other words, as long as the expected gross return on these bonds is $1 / \beta$.

The government is the only strategic agent in the model. After it has observed the actions of the bankers, which are summarized in the price $q$, it chooses whether or not to default, $z$, which in turn determines the level of government spending, $g$, and the level of productivity, $a$. This choice is given by the policy functions $z\left(s, B^{\prime}, q\right)$ and $g\left(s, B^{\prime}, q\right)$. The state of the government when it chooses $B^{\prime}$ is simply the initial state $s$. It knows, however, what the price $q\left(s, B^{\prime}\right)$ and its own optimizing choices $g\left(s, B^{\prime}, q\left(s, B^{\prime}\right)\right)$ and $z\left(s, B^{\prime}, q\left(s, B^{\prime}\right)\right)$ will be later. The government's value function is defined by the functional equation

$$
V_{g}(s)=\max _{B^{\prime}} c\left(K, s, B^{\prime}, g, z\right)+v(g)+\beta E V_{g}\left(s^{\prime}\right)
$$




$$
\begin{aligned}
& g=g\left(s, B^{\prime}, q\left(s, B^{\prime}\right)\right) \\
& z=z\left(s, B^{\prime}, q\left(s, B^{\prime}\right)\right) \\
& s^{\prime}=\left(B^{\prime}, K^{\prime}\left(s, B^{\prime}, g, z\right), a(s, z), \zeta^{\prime}\right) .
\end{aligned}
$$

Given this value function, we can now define the policy functions $g\left(s, B^{\prime}, q\right)$ and $z\left(s, B^{\prime}, q\right)$ as the solutions to

$$
\begin{aligned}
& \max _{g, z} c\left(K, s, B^{\prime}, g, z\right)+v(g)+\beta E V_{g}\left(s^{\prime}\right) \\
& \text { subject to } \\
& g+z B \leq \theta(a(s, z) f(K)-\delta K)+q B^{\prime} \\
& z=0 \text { or } z=1 \\
& g \geq 0 \\
& s^{\prime}=\left(B^{\prime}, K^{\prime}\left(s, B^{\prime}, g, z\right), a(s, z), \zeta^{\prime}\right) .
\end{aligned}
$$

This formulation says that the government realizes that it can effect consumption and investment $c$ and $K^{\prime}$, the production parameter $a$, and the price of its bonds $q$.

Having developed these concepts, we can now define a recursive equilibrium for our model economy.

Definition of an equilibrium. An equilibrium is a list of value functions, $V_{c}$ for the representative consumer, $V_{b}$ for the representative banker, and $V_{g}$ for the government; of policy functions, $c$ and $k^{\prime}$ for the consumer and $B^{\prime}, g$, and $z$ for the government; of a price function, $q$; and of an equation of motion for the aggregate capital stock, $K^{\prime}$, such that

- Given $B^{\prime}, g$, and $z, V_{c}$ is the value function for the solution to the representative consumer's problem, and $c$ and $k^{\prime}$ are the maximizing choices.

- Given $B^{\prime}, q$, and $z, V_{b}$ is the value function for the solution to the representative banker's problem, and the value of $B^{\prime}$ chosen by the government solves the problem when $b=B$.

- Given $q, c, K^{\prime}, g$, and $z, V_{g}$ is the value function for the solution to the government's 
problem, and $B^{\prime}$ is the maximizing choice. Furthermore, given $c, K^{\prime}, V_{g}$, and $B^{\prime}, g$ and $z$ maximize consumer welfare subject to the government's budget constraint.

- $q\left(s, B^{\prime}\right)=\beta E z\left(s^{\prime}, B^{\prime}\left(s^{\prime}\right), q\left(s^{\prime}, B^{\prime}\left(s^{\prime}\right)\right)\right)$, where

$$
s^{\prime}=\left(B^{\prime}, K^{\prime}\left[s, B^{\prime}, g\left(s, B^{\prime}, q\left(s, B^{\prime}\right)\right), z\left(s, B^{\prime}, q\left(s, B^{\prime}\right)\right)\right], a\left[s, z\left(s, B^{\prime}, q\left(s, B^{\prime}\right)\right)\right], \zeta^{\prime}\right) .
$$

- $K^{\prime}\left(s, B^{\prime}, g, z\right)=k^{\prime}\left(K, s, B^{\prime}, g, z\right)$.

While fairly technical in nature, this definition of equilibrium makes clear the nature of the strategic interaction between the government on one side and consumers and bankers on the other: Although consumers and bankers behave competitively, they understand that the government resolves its maximization problem every period. In particular, they understand that in some circumstances the government will choose to default. Although the government is benevolent, it understands that its actions affect the actions of consumers and, through the price of bonds, those of bankers.

Our definition of an equilibrium is similar to Chari and Kehoe's $(1990,1993)$ definition of a sustainable equilibrium and Stokey's (1991) definition of a credible equilibrium. It differs in two respects, however: First, since we have restricted ourselves to Markov equilibria, the agents' future conditional plans can be derived from their policy functions. Second, since we have allowed the private agents to condition their actions within the period on the government's new borrowing level, we do not have to assume that the government sets the prices and that the private agents set the quantities.

The complication in the definition of equilibrium of the model comes from the equilibrium condition for the price function $q\left(s, B^{\prime}\right)$. Cole and Kehoe (1996a) construct equilibria where, if $B^{\prime}$ is in the crisis zone, then $q\left(s, B^{\prime}\right)=\beta(1-\pi)$ if $\zeta \geq \pi$ and $q\left(s, B^{\prime}\right)=0$ if $\zeta<\pi$. In other words, bankers are willing to purchase new government debt for a price that includes a risk premium that depends on the probability of a crisis, which is $\pi$, if there is a favorable realization of the sunspot variable; they are unwilling to purchase new government debt at any positive price and a crisis occurs if there is an unfavorable realization of the sunspot variable. If $B^{\prime}$ is sufficiently low, however, $q\left(s, B^{\prime}\right)=\beta$ and no crisis can occur no matter 
what the realization of the sunspot variable. The crucial value $\pi$ is arbitrary: For every $\pi$, $0 \leq \pi \leq 1$, there is an equilibrium. In particular, $\pi=0$, where self-fulfilling crises do not occur, is always a possible equilibrium.

\section{Computation of Equilibria}

In this section we explain how to compute an equilibrium of the model described in the previous two sections. The equilibrium that we compute has the following features: The current level of government debt is the crucial determinant of the behavior of consumers, bankers, and the government. If the level of debt is low enough so that the government would pay it even if it was unable to sell new debt, then no crisis is possible. Consumers choose a constant high level of capital accumulation; bankers do not demand a risk premium on the return to government bonds; and the government maintains a constant level of debt. If, on the other extreme, the level of debt is high enough so that the government would default even if it could sell new debt, or if a default has already occurred, then the situation is dire. Consumers choose a low level of capital accumulation; bankers will not buy government debt at any positive price; and the government finances all its spending out of tax revenues. In between these two extremes is the crisis zone. Here self-fulfilling debt crises can occur with fairly arbitrary probability. Consumers choose a level of capital accumulation that is lower the higher the probability of a crisis; bankers demand a risk premium on the return to government; and the government may choose to reduce its spending to run down its debt and to eventually leave the crisis zone. For some parameters and a high enough level of initial government debt, however, the government may choose to maintain a constant debt level (see Cole and Kehoe 1996a).

We begin by characterizing consumers' and bankers' behavior for a fixed probability of default in the next period. The characterization of consumer behavior is greatly facilitated by the risk neutrality of utility in private consumption. Consider, for example, a consumer in period $t$, where default has not occurred, who assigns a probability $\pi$ to default in period $t+1$.

Fixing $k_{t}, k_{t+2}^{n}$, and $k_{t+2}^{d}$, this consumer chooses $c_{t}, k_{t}, c_{t+1}^{n}$, and $c_{t+1}^{d}$ to solve the variational 
problem

$$
\begin{aligned}
& \max c_{t}+\beta\left[(1-\pi) c_{t+1}^{n}+\pi c_{t+1}^{d}\right] \\
& \text { subject to } \\
& c_{t}+k_{t+1}-k_{t} \leq(1-\theta)\left(f\left(k_{t}\right)-\delta k_{t}\right) \\
& c_{t+1}^{n}+k_{t+2}^{n}-k_{t+1} \leq(1-\theta)\left(f\left(k_{t+1}\right)-\delta k_{t+1}\right) \\
& c_{t+1}^{d}+k_{t+2}^{d}-k_{t+1} \leq(1-\theta)\left(\alpha f\left(k_{t+1}\right)-\delta k_{t+1}\right) \\
& c_{t}, c_{t+1}^{n}, c_{t+1}^{d}, k_{t+1} \geq 0 .
\end{aligned}
$$

Here, for example, $c_{t+1}^{n}$ is the consumption in period $t+1$ contingent on no default and $k_{t+2}^{n}$ is the capital accumulation. The first-order conditions for this problem imply that capital accumulation is stationary at the level $k^{\pi}$ determined by

$$
(1-\theta)\left[(1-\pi+\pi \alpha) f^{\prime}\left(k^{\pi}\right)-\delta\right]=1 / \beta-1 .
$$

Consumption is

$$
c^{\pi}(k)=(1-\theta)(f(k)-\delta k)-k^{\pi}+k .
$$

In the case where no default is possible, we can derive the optimal level of capital accumulation $k^{n}$ and the consumption rule $c^{n}(k)$ by setting $\pi=0$. In the case where default has already occurred, we can derive the optimal level of capital accumulation by solving

$$
(1-\theta)\left(\alpha f^{\prime}\left(k^{d}\right)-\delta\right)=1 / \beta-1 .
$$

The optimal consumption rule is

$$
c^{d}(k)=(1-\theta)(\alpha f(k)-\delta k)-k^{d}+k .
$$

The behavior of bankers who expect default to occur with probability $\pi$ is even easier 
to describe: they purchase whatever amount of bonds that the government offers as long as

$$
q=\beta(1-\pi)
$$

Let us sketch out the strategy of presentation in the rest of this section: Cole and Kehoe (1996a) prove the existence of a recursive equilibrium in which consumers and bankers calculate the probability of government default based on the current level of the capital stock $K$, the current debt $B$, the realization of the sunspot variable $\zeta$, and the new debt issue $B^{\prime}$. Given the characterization of consumer and banker behavior for a given probability of default presented above, we can derive the behavior of the consumers and bankers implied by a guess as to the probability of default. Given the behavior of the consumers and bankers, we can then solve the government's dynamic programming problem to derive its optimal policies. Finally, given these policies, we can verify our guess as to the probability of government default.

There is a crucial level of current debt $\bar{b}_{1}(K)$ such that if $B \leq \bar{b}_{1}(K)$ the government will not default this period no matter what the realization of the sunspot variable. Consequently, if $B^{\prime} \leq \bar{b}_{1}\left(k^{n}\right)$, and default has not yet occurred, consumers expect no default next period and this implies that $K^{\prime}=k^{n}$ and $c=c^{n}(K)$. Similarly, if bankers believe that default will not occur this period, then bankers expect no default next period and this implies that $q=\beta$.

Consumers and bankers also expect, however, that there are levels of $B$ and $B^{\prime}$ high enough so that the government will choose to default no matter what the realization of the sunspot. More generally, they expect there is some constraint $B \leq \bar{B}\left(K, B^{\prime}, q\right)$ that must be satisfied for the government not to choose to default in the current period. Let $\bar{q}\left(K, B^{\prime}\right)$ be the price that bankers will pay for new debt $B^{\prime}$ in a period in which there will be no default and the current capital stock is $K$. For the bankers to believe that there will be no default in the current period, it must be that $B \leq \bar{B}\left(K, B, \bar{q}\left(K, B^{\prime}\right)\right)$. If, in addition, $B^{\prime} \leq \bar{b}_{1}\left(k^{n}\right)$, then $\bar{q}\left(K, B^{\prime}\right)=\beta$. If, however, $B^{\prime}>\bar{b}_{1}\left(k^{n}\right)$, but there exists some $B^{\prime \prime}$ such that $B^{\prime} \leq \bar{B}\left(k^{\pi}, B^{\prime \prime}, \bar{q}\left(k^{\pi}, B^{\prime \prime}\right)\right)$, then $\bar{q}\left(K, B^{\prime}\right)=\beta(1-\pi)$. For the moment let us concentrate on the stationary upper debt limit, that is, the maximum value of $B$ for 
which $B \leq \bar{B}(K, B, \bar{q}(K, B))$, which we denote $\bar{b}_{2}(K)$. If $\bar{b}_{1}(K)<B \leq \bar{b}_{2}(K)$, then a selffulfilling crisis occurs if the realization of the sunspot variable satisfies $\zeta<\pi$. Consequently, if $\bar{b}_{1}\left(k^{n}\right)<B^{\prime} \leq \bar{b}_{2}\left(k^{\pi}\right)$, then consumers and bankers expect a crisis to occur with probability $\pi$, and this implies that $q=\beta(1-\pi), K^{\prime}=k^{\pi}$, and $c=c^{\pi}(K)$.

Even if $B$ is above the stationary upper limit, Cole and Kehoe (1996a) show that default can sometimes be avoided by choosing a $B^{\prime}$ low enough so that $B \leq \bar{B}\left(K, B^{\prime}, \bar{q}\left(K, B^{\prime}\right)\right)$. For $B$ too high, however, the government cannot satisfy the constraint $B \leq \bar{B}\left(K, B^{\prime}, \bar{q}\left(K, B^{\prime}\right)\right)$ with any value of $B^{\prime}$; it therefore defaults immediately. Consumers and bankers expect that, if the government does not default in period 0 , then it will always chooses $B^{\prime}$ to satisfy the participation constraint $B \leq \bar{B}\left(K, B^{\prime}, \bar{q}\left(B^{\prime}\right)\right)$; otherwise bankers would set $q=0$.

We can now set up a single dynamic programming problem for the government. The value function for this problem is defined by the functional equation

$$
\begin{aligned}
V_{g}(s)= & \max _{B^{\prime}, g, z} c\left(s, B^{\prime}, z\right)+v(g)+\beta E V_{g}\left(s^{\prime}\right) \\
& \text { subject to } \\
& g+z B \leq \theta(a(s, z) f(K)-\delta K)+q\left(s, B^{\prime}\right) B^{\prime} \\
& s^{\prime}=\left(B^{\prime}, K^{\prime}\left(s, B^{\prime}, z\right), a(s, z), \zeta^{\prime}\right) \\
& z=0 \text { or } z=1 \\
& g \geq 0 .
\end{aligned}
$$

As we have explained, $c\left(B, K, a_{-1}, \zeta, B^{\prime}, z\right)$, for example, can take on the values $c^{n}(k), c^{\pi}(k)$, or $c^{d}(k)$ depending on $B, K, a_{-1}, \zeta, B^{\prime}$, and $z$. Solving this problem numerically is relatively easy: $B$ is the crucial state variable; except for $k_{0}, K$ can only take on the values $k^{n}, k^{\pi}$, and $k^{d} ; a$ can only take on the values 1 and $\alpha$; and $\zeta$ can be remodeled as a discrete random variable that takes the value 1 (no default) with probability $\pi$ and the value 0 (default) with probability $(1-\pi)$. Furthermore, once default occurs - so that $a=\alpha, K=k^{d}$, and $B=0$ - the problem can easily be solved analytically.

In the next section, we present the results of a numerical simulation of the model. In this section it remains only to check that our guesses of the probability of default used to derive consumer and banker behavior are, in fact, consistent with the government policies 
that we have computed.

The solution to the government's dynamic programming yields a default policy function $z\left(s, B^{\prime}, q\right)$. Consumers and bankers will be correct in expecting that the government will not default no matter what the realization of the sunspot variable if the government would choose not to default even if there is no new lending. In other words, if $z(s, 0,0)=1$. Consumers' and bankers' expectations are correct, therefore, if $\bar{b}_{1}(K)$ is the maximum value of $B$ such that

$$
z([B, K, 1, \zeta], 0,0)=1
$$

(The value of $\zeta$ is irrelevant in this calculation.) Consequently, $B>\bar{b}_{1}(K)$ is the no-lending continuation condition: the government chooses to default if there is no new lending when this condition is satisfied.

The government chooses not to default if $z\left(s, B^{\prime}, q\left(s, B^{\prime}\right)\right)=1$. Consumers' and bankers' expectations that the government will not default when there is new lending will be correct if $\bar{B}\left(K, B^{\prime}, q\right)$ is the maximum value of $B$ such that

$$
z\left([B, K, 1, \zeta], B^{\prime}, \bar{q}\left(B^{\prime}\right)\right)=1
$$

The stationary upper debt limit $\bar{b}_{2}(K)$ is the maximum value of $B$ such that

$$
z\left([B, K, 1, \zeta], B^{\prime}, \beta(1-\pi)\right)=1
$$

Consequently $B \leq \bar{B}\left(K, B^{\prime}, q\left(B^{\prime}\right)\right)$ is the participation constraint: the government chooses not to default if it is able to sell new debt.

Let $\bar{B}_{2}(K)$ be the maximum value of $\bar{B}\left(K, B^{\prime}, q\left(B^{\prime}\right)\right)$ for all values of $B^{\prime}$. The crisis zone, where a self-fulfilling debt crisis can occur, is the interval $\bar{b}_{1}(K)<B \leq \bar{B}_{2}(K)$. Cole and Kehoe (1996a) show that such a crisis zone exists for a wide range of parameters. We present a numerical example with a large crisis zone in the next section.

\section{A Numerical Example}

This section presents a numerical example whose parameters have been chosen so that the initial period matches, in a stylized way, the situation of Mexico in late 1994. In the 
next section we use the model to help us interpret events in Mexico in December 1994 and January 1995. We show that the crisis zone for our stylized model of Mexico is fairly large, and we characterize optimal government policy when the government finds its debt position in this zone.

In our example we interpret a period as being two-thirds of a year. This period length is chosen to match the average maturity of the Mexican government's short-term (that is, domestic) debt. The utility function for the consumers and the government is

$$
E \sum_{t=0}^{\infty} 0.97^{t}\left(c_{t}+\log \left(g_{t}\right)\right)
$$

The discount factor of 0.97 corresponds to a yearly discount factor of $0.955\left(=0.97^{3 / 2}\right)$, which implies a yearly yield of $0.047\left(=0.955^{-1}-1\right)$ on risk-free bonds - to be thought of as U.S. treasury bills. If we set the probability of default to be $\pi=0.02$, then the yearly yield on Mexican government bonds - to be thought of as tesobonos — would be 0.079 $\left(=[(0.97)(0.98)]^{-3 / 2}-1\right)$. Consequently, there would be a 3 percent risk premium on the Mexican government bonds. These numbers roughly match the average yields on 90-day U.S. T-bills and 91-day tesobonos during 1994 (see, for example, Kehoe 1995).

The choice of the functional form $v(g)=\log (g)$ is somewhat arbitrary. In comparison with a function that displays more curvature, such as $v(g)=-g^{-1}$, this function allows the government a fair amount of substitutability in government consumption over time. This, in turn, allows the government flexibility in reducing its expenditure to be able to pay off old debt in the event of no lending. Consequently, setting $v(g)$ equal to $\log (g)$ rather than to $-g^{-1}$ increases the upper level of the debt for which $B \leq \bar{b}_{1}\left(k^{n}\right)$ and for which no crisis can occur. Since the main point of this section is to show that crises can occur for fairly low levels of debt, our choice of $v(g)$ biases, if anything, the results against us.

The technology is given by the feasibility constraint

$$
c+g+k^{\prime}-0.95 k+z B \leq 2 k^{0.4}+q B^{\prime}
$$

The choice of $\delta=0.05$ corresponds to a yearly depreciation rate of $0.074\left(=1-0.95^{3 / 2}\right)$. The 
capital share 0.4 is lower than that in Mexico's national income and product accounts, but the published numbers include income of self-employed workers in capital income. The constant in the production function is a scaling factor which only influences the results because the utility function $c+\log (g)$ is not homothetic.

If consumers expect default to occur next period with probability $\pi=0.02$, they set $k^{\prime}=k^{\pi}$ where $k^{\pi}$ solves

$$
(1-\theta)\left[(0.98+0.02 \alpha) 0.8\left(k^{\pi}\right)^{-0.6}-0.05\right]=1 / 0.97-1 .
$$

Setting $\theta=0.2$ and $\alpha=0.95$ - which implies that Mexico would incur a permanent drop in productivity of 5 percent if it were to default - we obtain a capital stock of $k^{\pi}=$ 39.04 and a yearly GDP of $(3 / 2) 2\left(k^{\pi}\right)^{0.4}=12.99$, for a capital/output ratio of 3.00 . The investment/GDP ratio is $0.05 k^{\pi} /\left(2\left(k^{\pi}\right)^{0.4}\right)=0.23$ (Banco de México 1995, p. 206, reports a ratio of 0.22 in Mexico in 1994). Government revenues as a fraction of GDP are 0.2(2( $\left.k^{\pi}\right)^{0.4}-$ $\left..05 k^{\pi}\right) /\left(2\left(k^{\pi}\right)^{0.4}\right)=0.15$ (Banco de México 1995, p. 237, reports a figure of 0.17).

A crucial parameter in our simulation is the initial value of government, $B_{0}$. Choosing this parameter is complicated by the different types of debt obligations that Mexico had outstanding in 1994 and by the devaluation at the end of 1994 that sharply lowered the value of GDP compared to those obligations that were indexed to, or denominated in, U.S. dollars. For the sake of discussion in this section, we choose $B_{0}=2$ for a debt/GDP ratio of 0.15 , which is on the low side. We return to this issue in the next section.

In the model, $\bar{b}_{1}\left(k^{\pi}\right)=1.32$ and $\bar{B}_{2}\left(k^{\pi}\right)=8.49$, which as fractions of GDP are 0.10 and 0.65 respectively. Consequently, if $k_{0}=k^{\pi}$, the crisis zone is large: a self-fulfilling debt crisis can occur in the first period for any level of initial debt that satisfies $1.32<B_{0} \leq$ 8.49. Figure 1 graphs the optimal government debt policy function $B^{\prime}(K, B, 1, \zeta)$ for the government assuming that no crisis (and hence no default) occurs this period, that $K=k^{n}$ if $B \leq \bar{b}_{1}\left(k^{n}\right)=1.34$, and that $K=k^{\pi}$ if $\bar{b}_{1}\left(k^{n}\right)<B \leq \bar{B}_{2}\left(k^{\pi}\right)=8.49$. Notice that this function is piecewise linear: for $B \leq \bar{b}_{1}\left(k^{n}\right), B^{\prime}=B$; for $B$ higher than $\bar{b}_{1}\left(k^{n}\right)$ (between 0.10 and 0.17 as a fraction of GDP) it is optimal to run the debt down to $\bar{b}_{1}\left(k^{n}\right)$ in one period; for $B$ still higher (between 0.17 and 0.22 as a fraction of GDP) it is optimal to run the debt 
down to $\bar{b}_{1}\left(k^{n}\right)$ in two periods; and so on. For $B$ above $8.49(0.65$ as a fraction of GDP) the optimal policy is to default immediately.

It is worth making several comments about this optimal policy: First, if $\pi<0.02$, then $\bar{b}_{1}\left(k^{n}\right)$ stays the same, but the policy function gets closer to the 45 degree line: it is optimal to run the debt down to $\bar{b}_{1}\left(k^{n}\right)$ more slowly. The intuition for this result is simple. Reducing the probability of a crisis during the periods for which $B>\bar{b}_{1}\left(k^{n}\right)$ reduces the net gain from rapidly reducing the government debt to $\bar{b}_{1}\left(k^{n}\right)$. For example, the gain from reducing the debt to $\bar{b}_{1}\left(k^{n}\right)$ in one period as opposed to two periods is reduced since the likelihood of a crisis during the extra period is smaller, but the cost of reducing the government debt more abruptly to reach $\bar{b}_{1}\left(k^{n}\right)$ in one period is unchanged. As $\pi$ tends to 0 , the policy function tends towards the 45 degree line and $\bar{B}_{2}\left(k^{\pi}\right)$ increases towards 13.32 (1.03 as a fraction of GDP).

Second, choosing a utility function such as $v(g)=-g^{-1}$ would, as we have explained, give the government less ability to vary $g$. This would have the effect of shifting the whole crisis zone inwards - lowering $\bar{b}_{1}\left(k^{n}\right)$ and $\bar{B}_{2}\left(k^{\pi}\right)$ - and moving the policy function closer to the diagonal.

Third and finally, although all of our previous analysis has assumed that the government has the same discount factor $\beta$ as do consumers and bankers, it is easy to allow the government to have a different discount factor: We leave the form of the policy function for the consumers, $c$ and $k$, and that of the price function for bonds, $q$, the same as before, although the crucial values of $B$ change. We then solve the government's programming problem with a discount factor $\gamma \neq \beta$. Assuming that political constraints and the fixed six-year term of office in Mexico tend to make the government more impatient than consumers and bankers, we have experimented with several cases of $\gamma<\beta$. Figure 2 reports the optimal government debt policy function for the case $\gamma=0.93$, which corresponds to an annual discount factor of $0.90\left(=0.93^{3 / 2}\right)$. The crisis zone shrinks because $\bar{b}_{1}\left(k^{n}\right)$ falls only very slightly, but $\bar{B}_{2}\left(k^{\pi}\right)$ falls significantly (from 0.65 to 0.33 as a fraction of GDP). For $B<\bar{b}_{1}\left(k^{n}\right)$, it is optimal for the government to run its debt up to $\bar{b}_{1}\left(k^{n}\right)$, because its discount rate, $1 / \gamma-1$, is greater than the interest rate on its bonds, $1 / \beta-1$. For $B$ slightly above $\bar{b}_{1}\left(k^{n}\right)$ it is optimal to run down the debt to $\bar{b}_{1}\left(k^{n}\right)$ to avoid the possibility of default. At some level of $B(0.17$ as a 
fraction of GDP) it becomes optimal to run debt up to its upper limit, $\bar{B}_{2}\left(k^{\pi}\right)$.

\section{The 1994-95 Mexican Debt Crisis}

The model developed in this paper provides us with a framework in which we can interpret the Mexican debt crisis of December 1994 and January 1995. We argue that the events leading up to the debt crisis were such that defaulting on the debt was a discrete event and was likely to result in a discrete cost to the Mexican economy, and further, that these events had led to a simultaneous reduction in the average maturity of the Mexican government's debt and in its ability to repay in case it was unable to roll over these debts. We also argue that these events, along with the initial unwillingness of the international community to provide liquidity, made a crisis equilibrium possible. While the multiplicity of equilibria of the model means that it is completely silent as to why some countries might experience a crisis while others do not, events in Mexico suggest that the ongoing internal political turmoil within the country probably played an important role.

In an effort to keep its debt service low, the Mexican government steadily converted its peso-denominated debt-cetes, longer-term bondes, and inflation-indexed, longer-term ajustabonos - into short-term, dollar-indexed tesobonos. These tesobonos were sold by the Banco de México in weekly auctions. The Banco received bids in U.S. dollars at 9:30 am on Tuesdays. An 11:00 a.m. fix of the peso-dollar exchange rate determined the peso value of these bids. On Thursdays payment and deliveries were made. Tesobonos were issued in maturities that were multiples of 7 days - 91 days, 182 days, and 364 days - but most were 91-day bonds. The weekly calendar for settlements was the same as that for sales: the peso

value of maturing debt was determined by the 11:00 a.m. Tuesday fix, and settlements were made on Thursdays.

This conversion of the debt had two significant effects: First, it increased the Mexican government's dollar-indexed debt relative to its foreign reserves, as depicted in Figure 3. This dollar-indexed debt could not be inflated away. Instead, the only way that the Mexican government could decrease its tesobono liabilities was either to impose dual exchange rates, paying off tesobonos at an exchange rate lower than the market rate, or to suspend payments. The Mexican government had resorted to both these measures during the 1982 
financial crisis. Either or both measures would have imposed substantial costs on both the Mexican government and on the Mexican private economy, which we interpret as leading to a potentially low level of $a_{t}$.

Table 1

\section{Calendar of Maturing Debt 1995 Tesobonos and Cetes}

(millions of U.S. dollars)

$\begin{array}{cccc} & \text { Cetes } & \text { Tesobonos } & \text { Cetes plus Tesobonos } \\ \text { 1st quarter } & 3,015.00 & 9,873.94 & 12,888.94 \\ \text { 2nd quarter } & 1,563.47 & 6,429.26 & 7,992.72 \\ \text { 3rd quarter } & 1,042.66 & 8,425.70 & 9,468.36 \\ \text { 4th quarter } & 943.13 & 3,927.83 & 4,870.97\end{array}$

Source: International Monetary Fund (1995a).

While increasing the cost of default is a commonly proposed means of ensuring credibility, the Mexican government had also substantially decreased the already short maturity of the debt, as depicted in Figure 4. A consequence of the shortening of the maturity of the debt can be seen in Table 1. The Mexican government had substantial amounts of tesobonos coming due during the first quarter of 1995. This meant that, despite the potentially high costs of default on its dollar-indexed liabilities, the costs of paying off the maturing debt in the event that they could not roll it over were potentially higher still.

An important feature of our model that is useful for interpreting events in Mexico in 1994 is that increasing the default penalty by decreasing $\alpha$ does not necessarily increase welfare: although it pushes both the participation constraint and the no-lending continuation condition outwards, it may leave a government whose debt level is still in the crisis zone worse off. 
The political turmoil that the country had been experiencing seems to have worsened the economic situation. Following the uprising in Chiapas in January 1994 and the assassination of Luis Donaldo Colosio, the presidential candidate of the ruling Partido Revolucionario Institutional (PRI) in March, Mexican and foreign investors began to move portfolio investment out of Mexico. This had already led to a substantial drop in the government's foreign reserves because of its policy of sterilizing this outflow. In November, the resignation of the assistant attorney general, Mario Ruiz Massieu, who had been charged with investigating the assassination of his brother, Jose Francisco Ruiz Massieu, the secretary general of the PRI, apparently caused another drop in Mexican foreign reserves, which were now already dangerously below the short-term dollar-indexed liabilities of the Mexican government. (See Kehoe 1995 for a rendition of these events.) As Table 2 indicates, its tesobonos maturing in early 1995 far exceeded the remaining foreign reserves of 5,881 million U.S. dollars left after the 20-22 December devaluation.

Immediately prior to devaluation, Mexico's domestic government debt represented about 12 percent of GDP, and its total government debt represented about 37 percent of GDP. Devaluation kept constant the dollar value of tesobonos in the domestic debt and of Brady bonds in total debt but substantially lowered the dollar value of GDP and government revenues. (The distinction between domestic debt and external debt concerns where the debt is sold and not who purchases it.)

At this point, we interpret the Mexican government as being clearly in the region $\bar{b}_{1}(K)<B \leq \bar{B}_{2}(K)$ where a crisis could occur. In late December and early January, amid rumors of impending dual exchange rates and suspension of payments, the Banco de México was unable to roll over its debt. The crisis was under way. As indicated in Table 2, the Banco de México, beginning with the 20 December auction, had increasing difficulty selling tesobonos. This situation continued through much of January. The International Monetary Fund (1995a) suggests that the results of the auctions in the latter part of January might have been manipulated to make them seem more positive than they appear. The debt crisis was finally resolved by the rescue package put together by U.S. president Bill Clinton and announced on 31 January 1995. 
Table 2

\section{Tesobonos Auctions}

$\begin{array}{cccc}\text { Date } & \begin{array}{c}\text { Yield } \\ \text { (in percent) }\end{array} & \begin{array}{c}\text { Amount Offered } \\ \text { (in millions of dollars) }\end{array} & \begin{array}{c}\text { Amount Sold } \\ \text { (in millions of dollars) }\end{array} \\ \text { 6 Dec 1994 } & 8.39 & 420 & 420 \\ \text { 13 Dec 1994 } & 8.23 & 375 & 375 \\ \text { 20 Dec 1994 } & 8.61 & 600 & 416 \\ \text { 27 Dec 1994 } & 10.23 & 600 & 28 \\ \text { 3 Jan 1995 } & 12.31 & 500 & 52 \\ \text { 10 Jan 1995 } & 19.63 & 400 & 63 \\ \text { 17 Jan 1995 } & 19.75 & 300 & 500 \\ \text { 24 Jan 1995 } & 21.40 & 50 & 155 \\ \text { 31 Jan 1995 } & 24.98 & 150 & \end{array}$

In evaluating events in Mexico, it is important to realize that the crisis was not caused by a large government debt/GDP ratio. Table 3 compares data from Mexico with data from some other countries that have not experienced such a severe crisis.

A word of caution: the model is not intended to explain the decline in the Banco de México's foreign reserves that occurred throughout 1994 nor the devaluation that occurred on 20-22 December 1994. It can, however, help us understand the run on Mexican government debt, especially dollar-indexed tesobonos, that occurred during December and January.

The Banco de México no longer sells tesobonos. 
Table 3

Debt/GDP Percentages for Selected Countries

$\begin{array}{cccccc} & 1990 & 1991 & 1992 & 1993 & 1994 \\ \text { Mexico } & 55.2 & 45.8 & 35.1 & 35.0 & 37.4 \\ \text { Belgium } & 130.7 & 132.6 & 134.4 & 141.3 & 140.1 \\ \text { France } & 40.4 & 41.1 & 45.6 & 52.9 & 56.8 \\ \text { Germany } & 43.4 & 42.7 & 47.3 & 51.8 & 54.6 \\ \text { Greece } & 77.7 & 81.7 & 88.6 & 117.1 & 119.8 \\ \text { Italy } & 100.5 & 103.9 & 111.4 & 120.2 & 122.6 \\ \text { Spain } & 48.7 & 49.9 & 53.0 & 59.4 & 63.5\end{array}$

Sources: International Monetary Fund (1995c).

Organisation for Economic Co-Operation and Development (1995).

\section{Maturity of the Debt}

The optimal government debt policy function that we have calculated indicates that a government that finds itself in the crisis zone should reduce its spending and run down its debt. In this section we suggest an alternative: by lengthening the maturity structure of the debt, the government can increase $\bar{b}_{1}\left(k^{n}\right)$ and, for a sufficiently long maturity structure, completely eliminate the possibility of crises.

To make our discussion of maturity structure simple, we consider a government policy that converts an initial quantity $B$ of one-period bonds becoming due into equal quantities $B_{N}$ of bonds of maturity $1,2, \ldots, N$. Henceforth, the government redeems $B_{N}$ bonds every period and sells $B_{N} N$-period bonds. If there is no possibility of a crisis, the price of an $N$-period bond is $\beta^{N}$. Maintaining the same level of government debt spending before and 
after this change and assuming that there was no crisis possible before the change, we obtain

$$
\begin{gathered}
g=\theta\left(f\left(k^{n}\right)-\delta k^{n}\right)-B+\beta B=\theta\left(f\left(k^{n}\right)-\delta k^{n}\right)-B_{N}+\beta^{N} B_{N} \\
B_{N}=\frac{1-\beta}{1-\beta^{N}} B .
\end{gathered}
$$

The payoff to the government, if it always repays its debts under the stationary policy for debt issue, is unaffected by changes in the maturity of the debt and is simply

$$
\left(c^{n}\left(k^{n}\right)+v\left(\theta\left(f\left(k^{n}\right)-\delta k^{n}\right)-(1-\beta) B\right)\right) /(1-\beta) .
$$

The payoff to the government from repaying even if it cannot sell any new debt is influenced by the maturity of the debt. This is because the government has to reduce its spending relative to its tax revenues by $B_{N}$ for $N$ periods, and hence its payoff is

$$
\left(c^{n}\left(k^{n}\right)+\left(1-\beta^{N}\right) v\left(\theta\left(f\left(k^{n}\right)-\delta k^{n}\right)-(1-\beta) B /\left(1-\beta^{N}\right)\right)+\beta^{N} v\left(\theta\left(f\left(k^{n}\right)-\delta k^{n}\right)\right) /(1-\beta) .\right.
$$

This payoff is increasing in $N$, the maturity of the debt, since it allows the government to smooth out over time the total reduction in government spending needed to repay the debt. The payoff to defaulting in the event of a crisis is unaffected by the change in maturity and is

$$
c^{d}\left(k^{n}\right)+\left(\beta c^{d}\left(k^{d}\right)+v\left(\theta\left(\alpha f\left(k^{n}\right)-\delta k^{n}\right)\right)\right) /(1-\beta) .
$$

Consequently, $\bar{b}_{1}^{N}\left(k^{n}\right)$, the maximum present value of the debt, $B$, for which the payoff from repaying is at least as great as the payoff from defaulting when no new borrowing is possible, is increasing in $N$.

Figure 5 presents the computed $\bar{b}_{1}^{N}\left(k^{n}\right)$ for our simple quantitative model. The results indicate that at an average maturity of 16 months Mexico would have been out of the crisis zone with a debt/GDP ratio of about 0.20 , which was roughly the magnitude of their domestic debt after devaluation. Figure 5 also displays the values of the stationary participation constraint, $\bar{b}_{2}^{N}\left(k^{n}\right)$, whose calculation is analogous to that of $\bar{b}_{1}^{N}\left(k^{n}\right)$, as a function of the maturity structure of the debt. Notice that it too is increasing in $N$, though much less 
significantly. Cole and Kehoe (1996a) show that as $N \rightarrow \infty$ these two curves coincide.

It is worth making two final points about lengthening the maturity structure: First, the government can do nothing to eliminate a crisis if one is currently occurring. If the nolending continuation condition is satisfied, then nothing the government can do in the market for new debt will prevent it from being optimal to default. When a crisis is occurring it is too late to change the maturity of the debt! Second, it is easy for the government to increase the maturity of its debt in this model because there is no cost of doing so. In a more general framework, there may be significant costs. One well-known example of such a cost arises from a worsening of the time consistency problem associated with setting the inflation tax. (See Calvo and Guidotti 1990, 1992 for more on models with this cost.)

\section{Concluding Comments}

A critical reader will want to ask two related questions about the model used in this paper: How useful is a model with multiple equilibria - a model that can explain different outcomes for the same fundamentals in the environment? and in applying the model, Why did this crisis occur in Mexico and not somewhere else? In interpreting the results of our model, the reader should bear in mind that the model does not predict that anything can happen; rather, it says that, if the level of the debt is in the crisis zone, a crisis can happen. If the government takes steps to move its debt level out of this zone, however, either by running its debt down or by lengthening its maturity, then there is a unique equilibrium in which no crisis can occur.

Alesina, Prati, and Tabellini (1990) present data that suggest the Italy was in the crisis zone in 1987 and 1988. As Carlos Vegh has pointed out to the authors, reputational considerations may have played an important role in allowing the crisis to occur in Mexico but not in Italy. Our sunspot equilibrium explanation, while different from an explanation that relies on reputation, is not incompatible: both stress that, in certain circumstances, something besides economic fundamentals may play a role in determining economic outcomes. 


\section{References}

Alesina, Alberto; Prati, Allesandro; and Tabellini, Guido. 1990. "Public Confidence and Debt Management: A Model and a Case Study of Italy," in Public Debt Management: Theory and History, ed. Rudiger Dornbusch and Mario Draghi. Cambridge: Cambridge University Press, 94-118.

Banco de México. 1995. The Mexican Economy 1995: Economic and Financial Developments in 1994, Policies for 1995. Banco de México.

Calvo, Guillermo A. 1988. "Servicing the Public Debt: The Role of Expectations." American Economic Review 78: 647-661.

Calvo, Guillermo A. and Guidotti, Pablo E. 1990. "Indexation and Maturity of Government Bonds: An Exploratory Model," in Public Debt Management: Theory and History, ed. Rudiger Dornbusch and Mario Draghi. Cambridge: Cambridge University Press, $94-118$.

Calvo, Guillermo A. and Guidotti, Pablo E. 1992. "Optimal Maturity of Nominal Government Debt: An Infinite-Horizon Model." International Economic Review 33: 895-919.

Chari, V. V. and Kehoe, Patrick J. 1990. "Sustainable Plans." Journal of Political Economy 98: $783-802$.

Chari, V. V. and Kehoe, Patrick J. 1993. "Sustainable Plans and Mutual Default." Review of Economic Studies 60: 175-195.

Cole, Harold L. and Kehoe, Timothy J. 1996a. "Self-Fulfilling Debt Crises." Unpublished manuscript.

Cole, Harold L. and Kehoe, Timothy J. 1996b. "Self-Fulfilling Debt Crises and Capital Flight." In progress. 
Giavazzi, Francesco and Pagano, Marco. 1990. "Confidence Crises and Public Debt Management," in Public Debt Management: Theory and History, ed. Rudiger Dornbusch and Mario Draghi. Cambridge: Cambridge University Press, 94-118.

International Monetary Fund. 1995a. International Capital Markets: Developments, Prospects, and Policy Issues. Washington, D.C.: International Monetary Fund.

International Monetary Fund. 1995b. International Financial Statistics Yearbook. Washington, D.C.: International Monetary Fund.

International Monetary Fund. 1995c. World Economic Outlook, May 1995. Washington, D.C.: International Monetary Fund.

Kehoe, Timothy J. 1995. "What Happened to Mexico in 1994-1995?" in Modeling North American Economic Integration, ed. Patrick J. Kehoe and Timothy J. Kehoe. Boston: Kluwer Academic Publishers, 131-147.

Organisation for Economic Co-Operation and Development. 1995. OECD Economic Outlook, June 1995. Washington, D.C.: Organization for Economic Co-Operation and Development.

Stokey, Nancy L. 1991. "Credible Public Policy." Journal of Economic Dynamics and Control 15: 627-656. 
Figure 1. GOVERNMENT DEBT POLICY FUNCTION

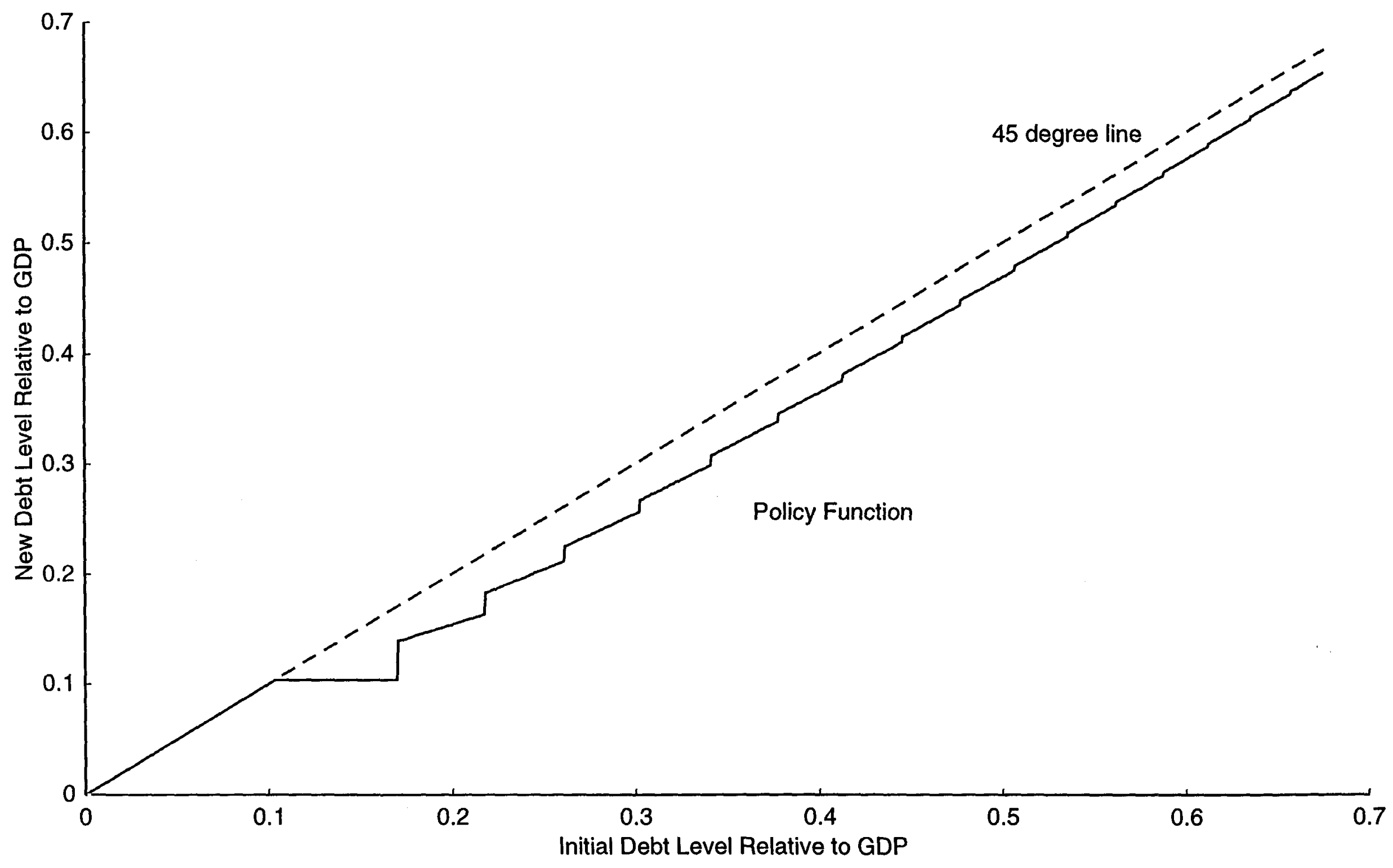


Figure 2. GOVERNMENT DEBT POLICY FUNCTION WITH GOVERNMENT DISCOUNT RATE 0.93

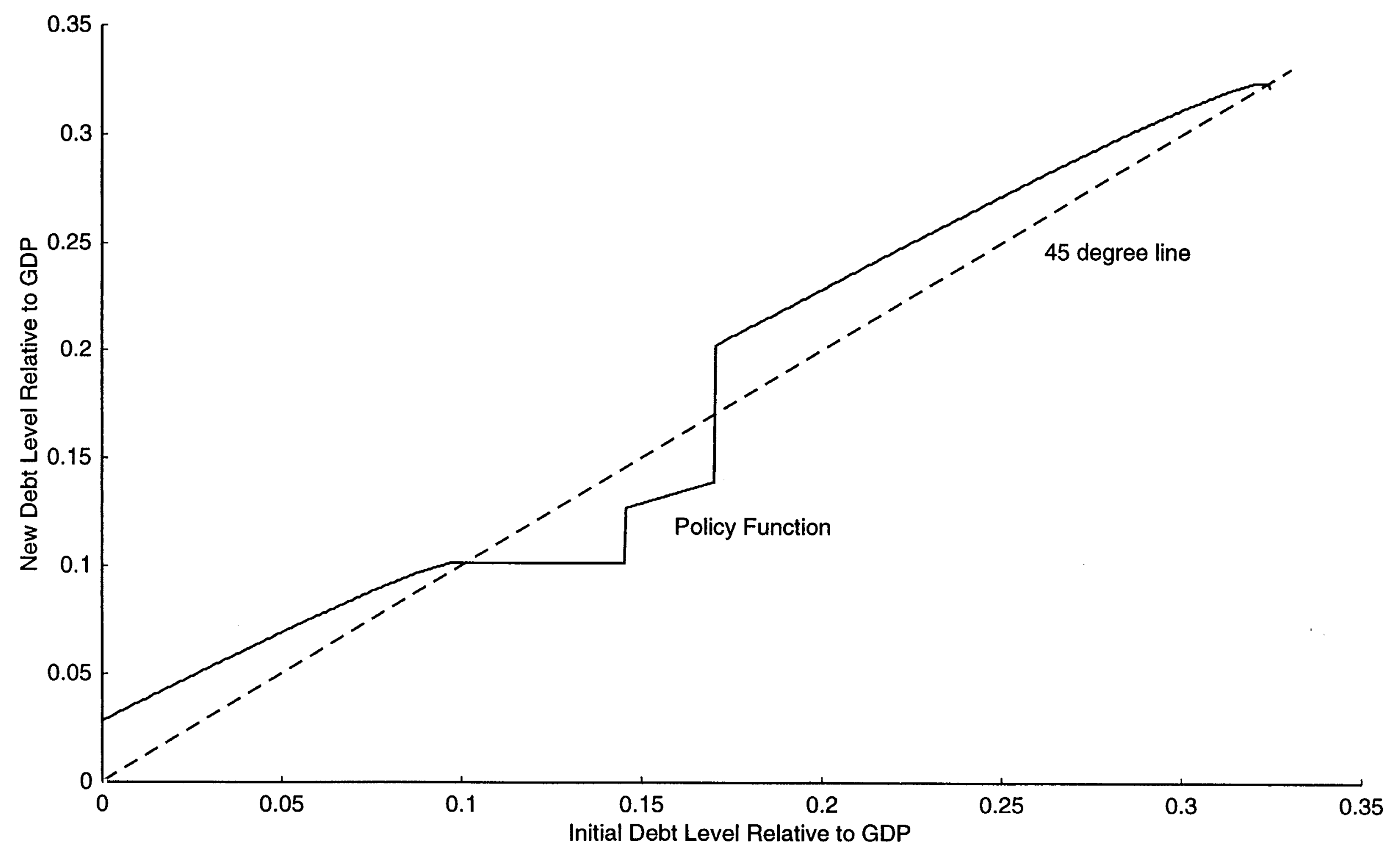


Figure 3. MEXICAN INTERNATIONAL RESERVES VS. GOVERNMENT BONDS

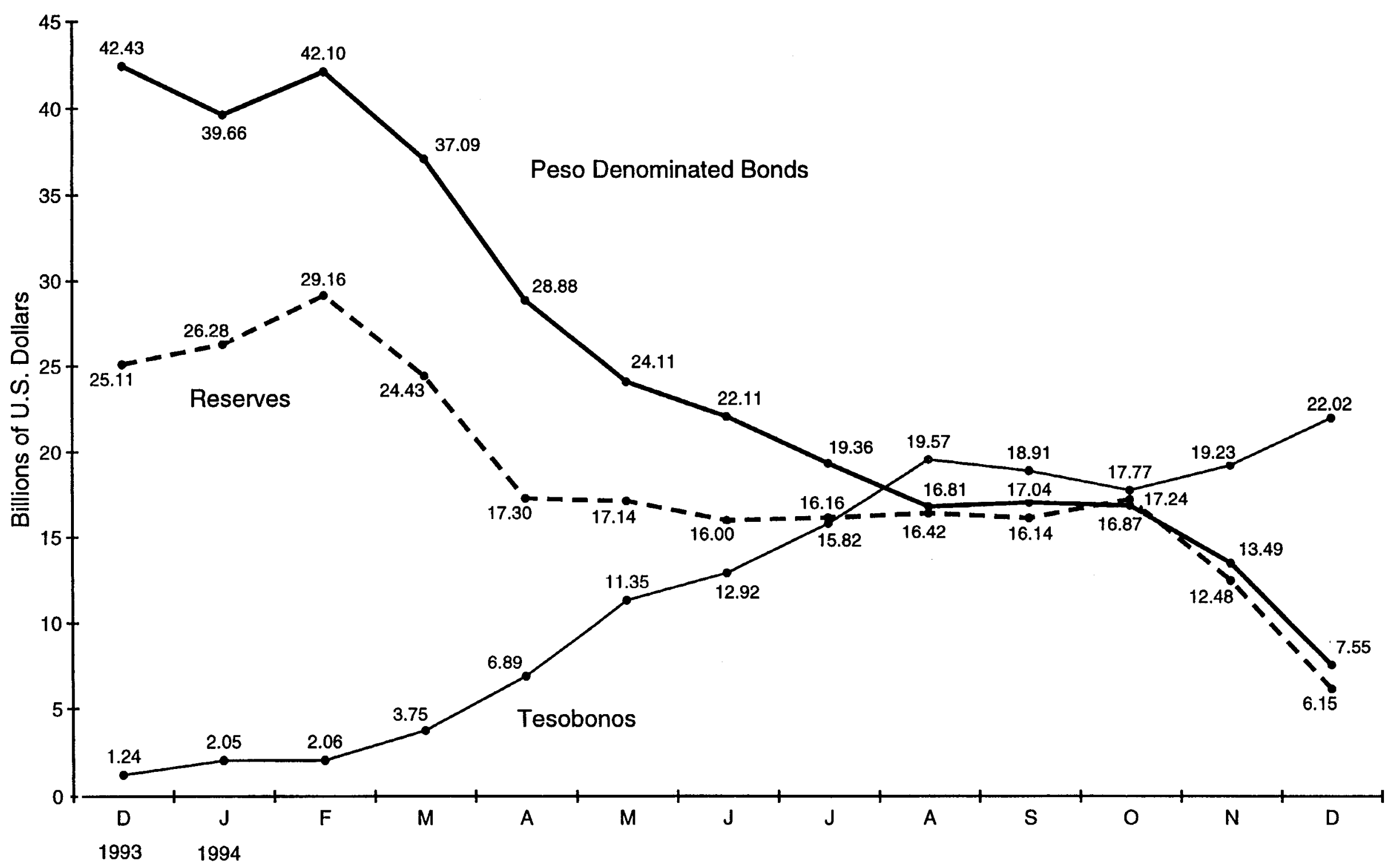

Source: Secretaría de Hacienda y Crédito Público 
Figure 4. AVERAGE MATURITY OF MEXICAN GOVERNMENT BONDS

(DAYS)

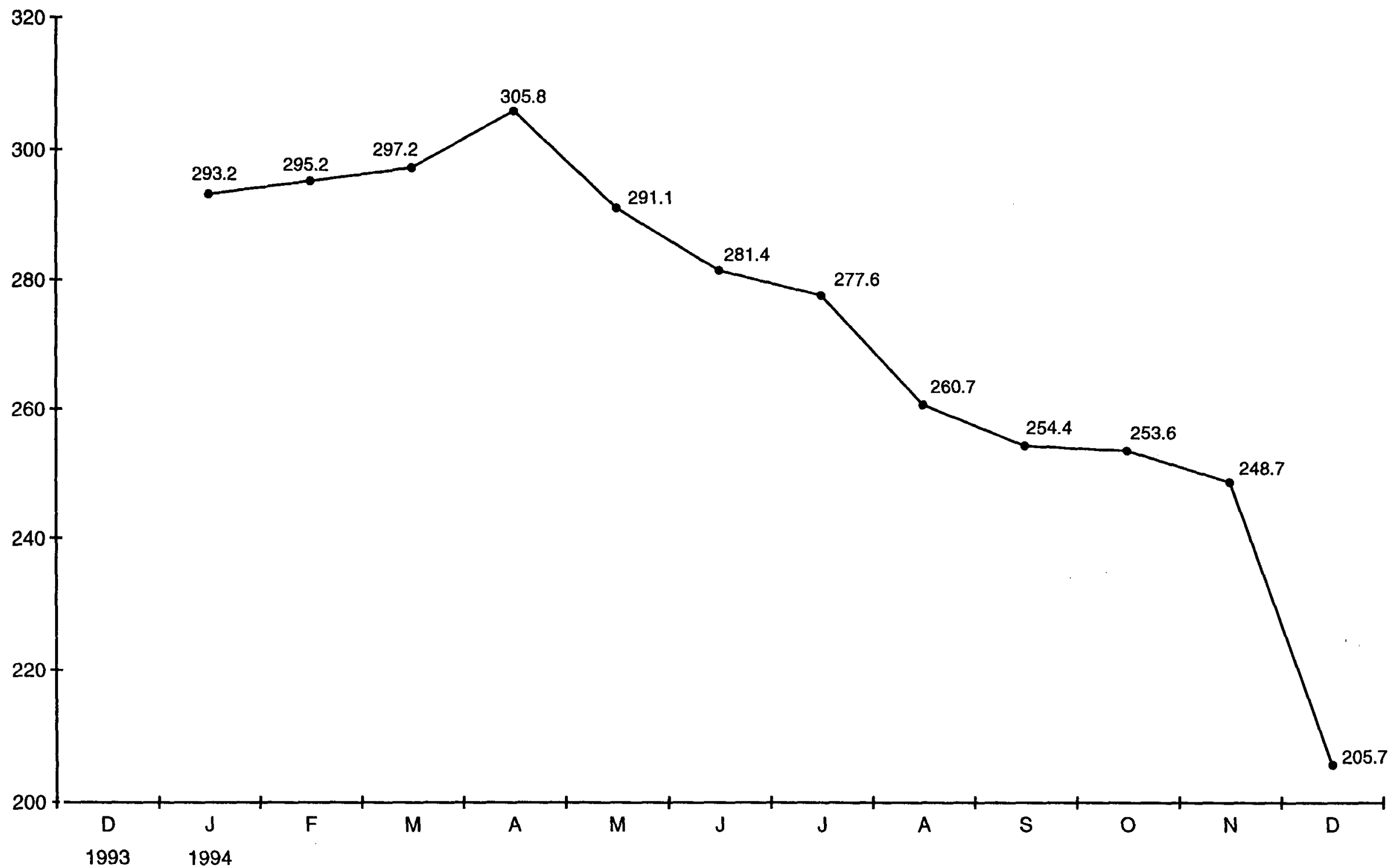

Source: Secretaría de Hacienda y Crédito Público 
Figure 5. AVERAGE MATURITY OF THE DEBT AND THE CRISIS ZONE

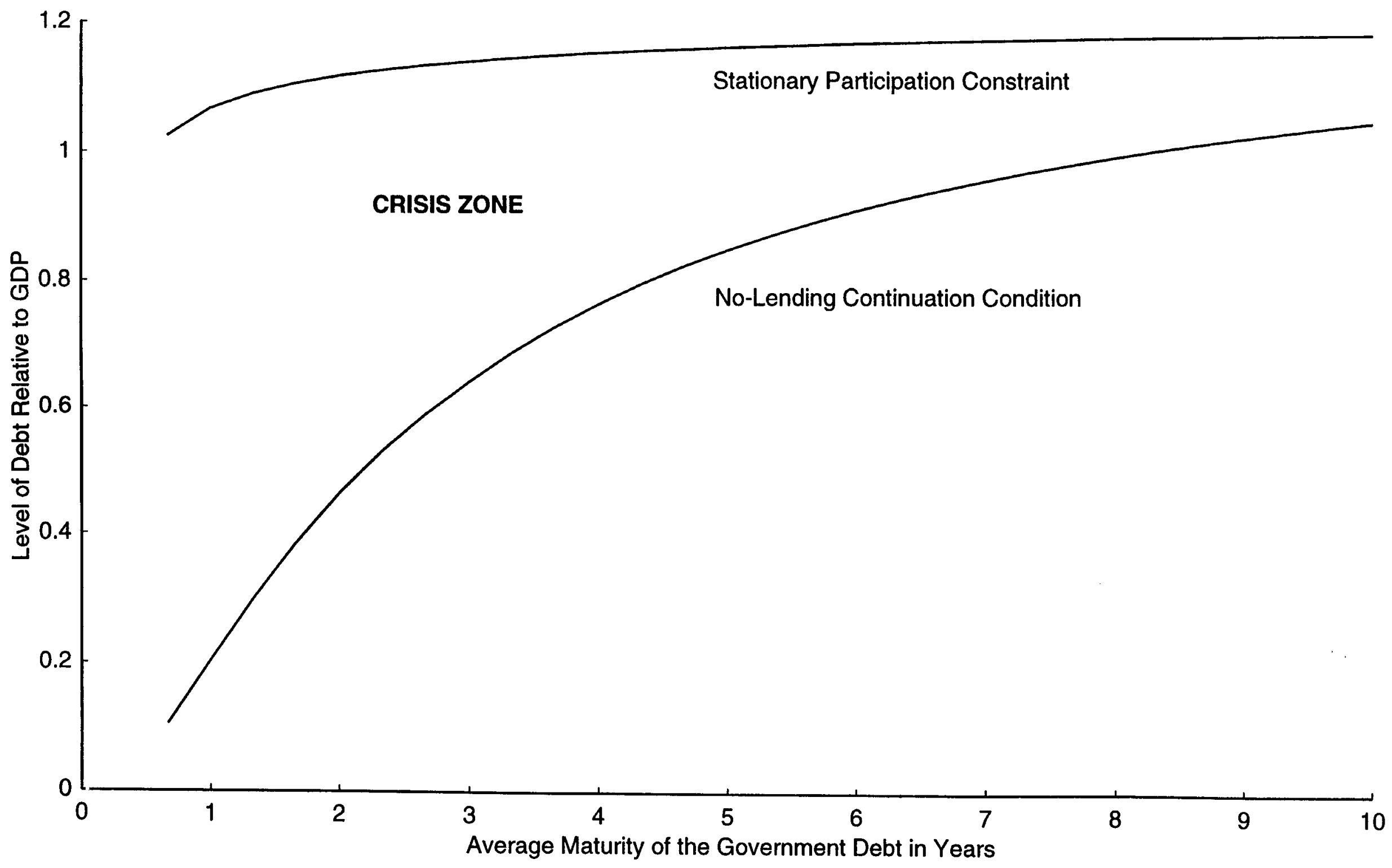

